\title{
CORRELATION OF PAP SMEAR AND COLPOSCOPIC FINDING OF CERVIX WITH HISTOPATHOLGIOCAL REPORT IN A GROUP OF PATIENT ATTENDING IN A TERTIARY HOSPITAL
}

\author{
PARVIN S ${ }^{1}$, KABIR N $^{2}$, LIPE YS ${ }^{3}$, NASREEN K ${ }^{4}$, ALAM KMN $^{5}$
}

\begin{abstract}
Objective: To correlate Pap's smear and colposcopic finding of cervix with histopathological report of abnormal area of cervix in a group of patient attending a tertiary hospital.

Methods: It was a cross-sectional prospective study done in one year period from January to December 2007 in Colposcopy Clinic of Institute of Child and Maternal Health (ICMH) Hospital, Dhaka. The study carried out including fifty two female patients having clinically unhealthy cervices as in the form of hypertrophy, erosion, congestion or bleeds on touch or having positive pap smear found during $P / V$ or $P / S$ examination, attending gynaecology out patient department of ICMH Hospital after fulfilling all the inclusion criteria.

Result: The present study showed a correlation between cervical cytology and colposcopically directed biopsy, the correlation was accurate within one grade in 39 of 51 cases (76.16\%) (as cytology was not done in one case). Other studies showed cytologic accuracy (within one level of histologic finding) to about $83 \%$ and $88 \%$ cases.

Conclusion: The study done here shows excellent correlation between findings of colposcopy with that of histopathology of guided biopsy. It also confirms the diagnostic value of colposcopy in the management of women with abnormal cervical cytology with squamous atypia.
\end{abstract}

Key words: Pap's smear, colposcopy, cervical histopathology.

\section{Introduction:}

World wide, cancer of cervix is the second most common cancer after the cancer of the breast ${ }^{1}$. In developoing countries cervical carcinoma comprises about $90 \%$ of all genital

1. Dr. Suraiya Parvin, Assistant Professor, Department of Obstetrics \& Gynaecology, International Medical College \& Hospital, Tongi, Gazipur.

2. Dr. Nazneen Kabir, Associate Professor \& Head, Department of Obstetrics \& Gynaecology, Institute of Child and Maternal Health (ICMH) Hospital, Matuail, Dhaka.

3. Dr. Yeasmin Samad Lipe, Medical Officer, Border Gaurd Bangladesh (BGB) Hospital, Dhaka.

4. Dr. Khaleda Nasreen, Lecturer, Department of Physiology, Sir Salimullah Medical College, Dhaka.

5. Dr. KM Nurul Alam, Registrar, Department of ENT, Mitford Hospital, Dhaka.

Correspondence: Dr. Suraiya Parvin, Assistant Professor, Department of Obstetrics \& Gynaecology, International Medical College \& Hospital, Tongi, Gazipur. E-mail: drshupa@gmail.com. malignancies ${ }^{2}$. Out of all cervical cancer cases seen in the world, only $14 \%$ are in the developed countries, while about $86 \%$ occurs in the developing countries ${ }^{3}$. An epidemiological study of cancer research Institute of Bangladesh 1976-81 shows that the prevalence of cancer cervix is $26 \%$ amongst all types of cancer affected females ${ }^{4}$.

World Health organization considers cervical cancer as a preventable disease. This is because it can be diagnosed in its precancerous phase ${ }^{3}$. As it is a preventable condition and almost curable when diagnosed early, that is, in its preinvasive stage (cervical intraepithelial neoplasia CIN), considerable efforts has been given into detecting and treating it in its preinvasive stage all over the world.

The concept of CIN (cervical intraepithelial neoplasia) was introduced by Richart, cited in Ratnam ${ }^{5}$ to encompass a group of epithelial abnormalities that were previously called dysplasia and carcinoma in situ. Dysplasia is regarded as a histopathological condition where 
part or whole thickness of cervical epithelium undergoes disordered growth and development. Severity of the condition is denoted by involvement of the thickness of cervical epithelium. In CIN I only basal third or less of the epithelium is occupied by undifferentiated cells. A lesion is classified as CIN ${ }^{\mathrm{II}}$ if the cells occupy between one third and two thirds of the epithelium. If undifferentiated cells occupy more than two-third of epithelial thickness, diagnosis of CIN III is made.

In all developed and is some developing countries, Pap's smear test has become a routine procedure for every gynecological patient for detection of cervical intraepithelial neoplasia and carcinoma cervix.

Papanicoloau and Traut, in 1941, refined the vaginal pool cellular collection technique for cytological screening of cervical cancer which would allow pre-invasive carcinoma to be recognized in a symptom less population and that treatment at this stages would prevent onset of cervical cancer and thus reduce the incidence of mortality from the disease ${ }^{7}$.

Pap's test is a cytodiagnostic tool done on superficial cells of genital tract particularly cervix. Exfoliative cytology that is study of cells which are shed off from various tissues of the body due to some physiological or some pathological process is the basis of the test. But cytology also cannot determine the extent or location of abnormality though it is highly accurate in predicting the presence of cervical neoplasia ${ }^{5}$. Ideally all women with abnormal cervical cytology should have colposcopic examination.

Colposcopy is a clinical method of detections of cervical cancer and CIN. Colposcope is a binocular microscope used for direct visualization of cervix. The interest in colposcope has developed recently may be due to erroneous concept that exfoliative cytology of the cervix renders colposcopy unnecessary where as colposcopy and cytology should correctly be regarded as complementary to each others $^{8}$.

It was stated in krutzen ${ }^{9}$ and Ratnam ${ }^{5}$ that colposcopy complements cytology and when combined with selective biopsy of the worst affected area allows a high level of diagnostic accuracy of $90.7 \%{ }^{9}$ and $95 \%{ }^{5}$ respectively. Using cytology for screening and colposcopy for directing the biopsy, a joint accuracy of approximately $90 \%$ to $99 \%$ can be achieved ${ }^{10}$.

Under the guidance for cervical screening programme, women with moderate or severe dyskaryosis or with persistent mild dyskaryosis of borderline change are referred for colposcopic examination of the cervis ${ }^{11}$. In a small number of these women, abnormalities are not observed at colposcopy or in biopsies taken at the time of that examination. These women are regarded as having had false positive smears ${ }^{6}$.

\section{Methods:}

It was a cross-sectional prospective study done in one year period from January to December 2007 in Colposcopy Clinic, Institute of Child and Maternal Health (ICMH) Hospital. The study carried out on fifty two female patients having clinically unhealthy cervices as in the form of hypertrophy, erosion, congestion or bleeds on touch or having positive pap smear found during $\mathrm{P} / \mathrm{V}$ or $\mathrm{P} / \mathrm{S}$ examination, attending gynaecology out patient department of ICMH Hospital. Firstly, the patients were explained about the procedure to be performed and verbal consent was obtained. Then detail clinical history was taken and physical examinations, colposcopy and directed biopsy were done. Data were recorded in a predesigned data collection sheet. The findings of Pap's smear report of the patients were noted.

\section{Results:}

The investigation results and observations are summarized in the following tables:

\section{Table-I}

Cytological findings in the study subjects

\begin{tabular}{lcc}
\hline Pap's Smear Findings & $\begin{array}{c}\text { Number } \\
(\mathrm{n}=52)\end{array}$ & $\begin{array}{c}\text { Percentage } \\
(\%)\end{array}$ \\
\hline Normal Cytology & 04 & 07.69 \\
Inadequate & 03 & 05.77 \\
Inflammatory change & 36 & 69.23 \\
Inflammation with & & \\
Atypical Squamous Cells & 04 & 07.69 \\
Dysplasia & & \\
$\quad$ - Mild & 03 & 05.77 \\
$\quad$ - Moderate & 01 & 01.92 \\
$\quad$ - Severe & 00 & 00 \\
Not Done & 01 & 01.92 \\
\hline
\end{tabular}


Table-II

Colposcopic impression in study subjects

\begin{tabular}{lcc}
\hline Colposcopic Impression & Number & $\begin{array}{c}\text { Percentage } \\
(\%)\end{array}$ \\
\hline Normal & 10 & 19.23 \\
Inflammation & 22 & 42.30 \\
CIN I & 13 & 25.00 \\
CIN II & 05 & 09.61 \\
CIN III & 00 & 00 \\
Invasive Carcinoma & 00 & 00 \\
Unsatisfactory & 02 & 03.84 \\
\hline
\end{tabular}

Table-III

Colposcopically Directed Biopsy (CDB) reports

\begin{tabular}{lcc}
\hline CDB & $\begin{array}{c}\text { Number } \\
\text { (52 sample) }\end{array}$ & $\begin{array}{c}\text { Percentage } \\
\text { (\%) }\end{array}$ \\
\hline Chronic Cervicitis & 24 & 46.15 \\
CIN I & 09 & 17.30 \\
CIN II & 05 & 9.61 \\
CIN III & 02 & 3.84 \\
Invasive Carcinoma & 02 & 03.84 \\
Not done & 10 & 19.23 \\
\hline
\end{tabular}

Table-IV

Correlation between $P / S$ findings and cytology in study subjects

\begin{tabular}{|c|c|c|c|c|c|c|c|c|}
\hline \multirow[b]{2}{*}{$\mathrm{P} / \mathrm{S}$ findings } & \multicolumn{3}{|c|}{ Cytology is study group } & \multirow[b]{2}{*}{ Mild } & \multicolumn{2}{|c|}{ Dysplasia } & \multirow{2}{*}{$\begin{array}{l}\text { Inade- } \\
\text { quate }\end{array}$} & \multirow{2}{*}{$\begin{array}{c}\text { Not } \\
\text { Done }\end{array}$} \\
\hline & $\begin{array}{l}\text { Normal } \\
\text { mation }\end{array}$ & $\begin{array}{l}\text { Inflam } \\
\text { th Sq. atypia }\end{array}$ & $\begin{array}{l}\text { Inflam- } \\
\text { mation }\end{array}$ & & Mod. & Severe & & \\
\hline Apparently Healthy & & & & & & & & 01 \\
\hline Cervix (2) & - & 0 & - & - & - & - & - & \\
\hline Hyper & & & & & & & & - \\
\hline trophied (35) & 05 & 25 & 01 & 01 & 01 & - & 04 & \\
\hline Erosion (22) & 02 & 18 & - & 01 & - & - & 01 & - \\
\hline Nabothian & & & & & & & & - \\
\hline Cyst (06) & 01 & 04 & - & 01 & - & - & - & \\
\hline Bleed on & & & & & & & & - \\
\hline Touch (18) & - & 11 & 02 & 03 & - & - & 02 & \\
\hline Excessive $\mathrm{P} / \mathrm{V}$ & & & & & & & & - \\
\hline Discharge & - & 11 & 01 & - & - & - & - & \\
\hline
\end{tabular}

Table-V

Correlation between cervical cytology and colposcpic impression

\begin{tabular}{|c|c|c|c|c|c|c|c|}
\hline \multirow{3}{*}{$\begin{array}{l}\text { Cervical } \\
\text { Cytology }\end{array}$} & \multicolumn{7}{|c|}{ Colposcopic Impression of Cervix in study group } \\
\hline & Normal & Inflam- & CIN & CIN & CIN & Invasive & Unsatis- \\
\hline & & mation & I & II & III & Carcinoma & factory \\
\hline Normal (4) & 03 & 01 & - & - & - & - & - \\
\hline Inflammatory (36) & 07 & 14 & 13 & 01 & - & - & 01 \\
\hline Inflammation with & & & & & & & \\
\hline atypical sq. cell (4) & - & 02 & - & 01 & - & - & 01 \\
\hline Mild Dysplasia (03) & - & 02 & 01 & - & - & - & - \\
\hline Moderate Dysplasia (01) & - & 01 & - & - & - & - & - \\
\hline Severe Dysplasia & - & 01 & - & - & - & - & - \\
\hline Inadequate (3) & - & 01 & 01 & - & - & - & 01 \\
\hline Not Done (1) & - & - & - & 01 & - & - & - \\
\hline
\end{tabular}


Table-VI

Correlation between cervical cytology and histopathology of colposcopically directed biopsy

\begin{tabular}{|c|c|c|c|c|c|c|}
\hline \multirow{3}{*}{$\begin{array}{l}\text { Cervical } \\
\text { Cytology }\end{array}$} & \multicolumn{5}{|c|}{ Histopathology of Colposcopically directed Biopsy } & \multirow[b]{3}{*}{ Carcinoma } \\
\hline & \multirow[t]{2}{*}{ Normal } & \multirow[t]{2}{*}{ Cervicitis } & \multicolumn{3}{|c|}{ Invasive } & \\
\hline & & & CIN I & CIN II & CIN III & \\
\hline Normal (4) & 03 & 01 & - & - & - & - \\
\hline Inflammatory (36) & 08 & 17 & 07 & 05 & - & - \\
\hline \multicolumn{7}{|l|}{ Inflammation with } \\
\hline Atypical sq. cell (4) & - & 01 & - & 02 & - & 01 \\
\hline Mild Dysplasia (3) & - & 01 & - & - & - & - \\
\hline Moderate Dysplasia (1) & - & 01 & - & - & - & - \\
\hline Severe Dysplasia & - & - & - & - & - & - \\
\hline Inadequate (3) & - & 01 & 01 & - & - & 01 \\
\hline Not Done (1) & - & - & - & 01 & 01 & - \\
\hline
\end{tabular}

\section{Discussion:}

The present study was carried out to evaluate and compare colposcopic finding with pap's smear finding among patient with unhealthy cervices attending the colposcopy clinic at ICMH during one year period from January to December 2007.

All of the 52 cases had undergone colposcopic examination and showed no abnormalities in 10 or $19.23 \%$ of the cases and a lesion in 42 cases, that is $80.76 \%$. The later were sampled by colposcopy-guided biopsy.

The biopsy samples showed evidence of CIN I in 9 cases (17.30\%), CIN II in 5 cases $(9.67 \%)$, CIN III in 2 (3.84\%), invasive carcinoma in two (3.84\%) and Inflammation in 24 cases $(46.15 \%)$ out of 52 cases. In one study carried out in Bangladesh, ${ }^{12}$ it was observed that the incidence of CIN I in $34.56 \%$, CIN II in $13.97 \%$, CIN III in $9.56 \%$, and invasive carcinoma in $4.41 \%$, which were quite higher than in our study. But in our study, rate of Inflammation was higher i.e. $46.15 \%$, where as the study mentioned above found, it lower i.e. $37.52 \%$. This discrepancy might be due to difference in the selection criteria of the study subjects, where our study was done on unhealthy cervices and that was on abnormal pap's smear group.

In our study, colposcopic impression was found accurate within one-step disparity of histological diagnosis in 38 of 42 patients (90.4\%), when it was compared to colposcopyguided biopsy. Two different studies showed accuracy of colposcopic impression to colposcopy-guided biopsy to $86 \%^{3}$ and $91.7 \%^{1}$ respectively. Hence our study correlates more with the findings of the second study. Another study ${ }^{14}$ carried out in Bangladesh, reported 91.9\% accuracy of colposcopic impression to colposcopically directed biopsy, here also present study report had similarity with the study report carried out in Bangladesh.

In the present study, 51 women were also evaluated for cervical neoplasia by cytology (in one case cytology was not done) and the reports were compared with colposcopy and also with colposcopically directed biopsy (CDB). Of the 51 patients, 36 patients showed inflammatory smears and among them colposcopy revealed inflammation among 14 patients $(37.83 \%)$, CIN I in $13(35.13 \%)$ and CIN II in $1(2.7 \%)$. There were 3 mild dysplasia cases on cytology but colposcopy showed CIN 1 in only 1 (33.3\%) case. Colposcopic impression and cytologic diagnosis were in agreement in 42 of 51 (62.35\%) patients. Shesadri et al showed cytologic accuracy within one level of colposcopic findings in $87.6 \%$ cases.

Of the 51 cases 36 cases showed inflammatory smears and biopsy reports of these inflammatory smears showed inflammatory 
changes in $44.44 \%$ (16 out of 36 ), CIN I in $19.44 \%$ ( 7 out of 36 ), CIN II in $13.88 \%$ (5 out of 36). Out of 36 inflammatory smears, 7 cases $19.44 \%$ seemed colposcopically normal and therefore biopsy were not done but were advised to come to repeat smear after six months. One study ${ }^{13}$ presents nine patients with persistent inflammation on cytology and had inflammation in 56\%, mild dysplasia in 33\% and normal in $11 \%$ on histopathologic diagnosis. The disparity between our study and the study referred above might be because their study was carried out on patients with persistent inflammation in the pap smear report where as in the present study sample subjects were selected randomly with unhealthy cervix.

In the present study 4 inflammatory smears were found in association with atypia. Of these 4 , one showed inflammation $(25 \%)$ and 2 cases (50\%) showed CIN II and one case $(25 \%)$ showed invasive carcinoma on biopsy. A similar study ${ }^{18}$ also found correlation between atypia with Dysplasia (63\%). It thus appears that women who show cytologic evidence of squamous atypia would benefit from colposcopic examination.

In this study, mild dysplasia on pap's smear showed CIN I in 66.6\% (2 of 3) on histology. The data of this study showed only one case of moderate dysplasia on smear that on histology revealed only inflammation.

None of the cases 51 out of 52 showed severe dysplasia on smear. One case of carcinoma in situ/CIN III was found on histology where pap's smear could not be performed. Among 52 cases, $3(7.69 \%)$ cases showed inadequate smear of which $33.33 \%$ ( 2 of 3 ) indicated inflammation, $33 \%$ ( 1 of 3 ) CIN 1 and other $33.33 \%$ were invasive carcinoma on histology following colposcopically directed biopsy. We recall all of the inadequate smear case and colposcopy was done. But it has been suggested that to repeat an inadequate smear after 6 months rather than arranging immediate recall ${ }^{15}$. One study showed that when clinician suspected cervical neoplasia but the pap's smear was negative, colposcopy revelaed at least grade II CIN in 5\% of patients. ${ }^{16}$ Such patients, therefore, need to be followed up closely or have a colposcopy and directed biopsy.
The present study showed a correlation between cervical cytology and colposcopically directed biopsy, the correlation was accurate within one grade in 39 of 51 cases $(76.16 \%$ ) (as cytology was not done on one case). Other studies showed cytologic accuracy (within one level of histologic finding) to about $83 \%{ }^{17}$ and $88 \%$ cases. ${ }^{10}$

The study done here shows excellent correlation between findings of colposcopy with that of histopathology of guided biopsy. It also confirms the diagnostic value of colposcopy in the management of women with abnormal cervical cytology with squamous atypia.

\section{Conclusion:}

The incidence of CIN was (30.76\%) in women with unhealthy cervix and $(15.38 \%)$ in women with positive pap smear. $37.83 \%$ of the patients with inflammatory pap smear, evealed CIN on colposcopy. $35.39 \%$ CIN I and $2.7 \%$ CIN II. Of the women with inflammatory smears and atypia $75 \%$ (50\% CIN II and 25\% invasive carcinoma) showed abnormality on biopsy. There is good correlation (76.16\%) between cervical cytology and colposcopically directed biopsy. There is a strong correlation (90.4\%) between colposcopic impression and histopathology following colposcopically directed biopsy.

\section{References:}

1. Shafi MI. Premalignant and Malignant disease of the cervix. In: Edmond DK. ed. Dewhurt's Text book obstetrics and gynaecology for post graduates. $6^{\text {th }}$ ed. New York: Blackwell Science; 1999. p.572-81.

2. Dutta DC, ed. Text Book of gynaecology. $4^{\text {th }}$ ed. New Delhi: New Central Book Agency; 2004. p.123

3. Suraiya UB. Cancer screening in gynecology. In: Ratnam SS, Rao KB, Arulkumar S. eds. Obstetrics and gynecology. New Delhi: Orient Longman; 1994. p.454-64.

4. Syaeeda N. Pap's smear - cervical cytology: a prospective clinical study of 500 cases in Dhaka Medical College Hospital. [Dissertation]. Dhaka: BCPS; 1996.

5. Sivanessartnam V. Pathology and management of CIN lesion of the cervix. In: Ratnam SS, Rao KB, Arulkumaran S. eds. Obstetrics and gynecology for post graduate. $2^{\text {nd }}$ ed. New Delhi: Orient Longman; 1999. p.364-79. 
6. Kurman RJ, Solomon D. The bethesda system for reporting cervical/vaginal cytologic diagnoses. Srpringe-Verlag, New York Inc, 1994; 44:48.

7. Papanicoloau G, Traut $H$. The diagnosis value of vaginal smears in carcinoma of outers. Am J Obstet Gynaecol 1941; 42: 193.

8. Howkins J, Hudson CN. eds. Shawl's text book of operative gynecology. $5^{\text {th }}$ ed. Edinburgh: Churclill Livingstone; 1983. p.37-67.

9. Khutzen VK, Sherwood AG. Colposcopy an selective Biopsy in patients with abnormal cervical cytology. S Afr Med J 1997; 52(12): 478-81.

10. Srisomboon J. Tangchitrong CA, Bhuswang Y. Chairatana A, Evaluation of colposcopic Accuracy in diagnosis of cervical neoplasia J Med Assoc Thai 1996; 79(7): 423-7.

11. Milne D.S, Wadehra V. Mennim D, Wagstaff T I. A prospective follow up study of women with colposcopically unconfirmed prospective cervical smears, Br J Obstet Gynaecol 1999; 106: 38-41.

12. Sultana F. Incidence of CIN in a group of patient presenting with clinically unhealthy cervix. [Thesis]. Dhaka: BSMMU; 1996.
13. Srisomboon J. Tangchitrong CA, Bhuswang Y. Chairatana A, Evaluation of colposcopic Accuracy in diagnosis of cervical neoplasia. J Med Assoc Thai 1996; 79(7): 423-7.

14. Ivy R. Colposcopic Evaluation of patients with abnormal Cervical Smear. [Thesis]. Dhaka: BSMMU; 1999.

15. Benedet JL, Boyes DD, Nichols TM, Millner A. Colposcopic evaluation of, patients with abnormal cervical cytology. Br J Obstet Gynaecol 1976; 83(3): 177-82.

16. Swinker M, Cuttip AC, Ogle D. A comparison of uterine cervical cytology and biopsy results: indications and outcomes for colposcopy. J Fam Pract 1994; 38(1): 40-4.

17. Hollingworth J, Kotecha K, Dobbob SP, Shaw PA, Ireland D. Cervical disease in women referred to colposcopy following inadequate smear. Cytopathol 2000; 11(1): 45-52.

18. Peedicayil A, Regi A, Mathai M, Jasper P. Colposcopy in women with a normal papanecolaou smear. Natl Med J India 1994; 7(5): 208-9. 